\title{
Diffusion of phosphorous in black silicon
}

Stilling-Andersen, Andreas R.; Solodovnikova, Olga ; Davidsen, Rasmus S.; Hansen, Ole; landolo, Beniamino

\author{
Published in: \\ 2018 IEEE 7th World Conference on Photovoltaic Energy Conversion (WCPEC) (A Joint Conference of 45th \\ IEEE PVSC, 28th PVSEC \& 34th EU PVSEC)
}

Link to article, DOI:

10.1109/PVSC.2018.8548096

Publication date:

2018

Document Version

Peer reviewed version

Link back to DTU Orbit

Citation $(A P A)$ :

Stilling-Andersen, A. R., Solodovnikova, O., Davidsen, R. S., Hansen, O., \& landolo, B. (2018). Diffusion of phosphorous in black silicon. In 2018 IEEE 7th World Conference on Photovoltaic Energy Conversion (WCPEC) (A Joint Conference of 45th IEEE PVSC, 28th PVSEC \& 34th EU PVSEC) IEEE.

https://doi.org/10.1109/PVSC.2018.8548096

\section{General rights}

Copyright and moral rights for the publications made accessible in the public portal are retained by the authors and/or other copyright owners and it is a condition of accessing publications that users recognise and abide by the legal requirements associated with these rights.

- Users may download and print one copy of any publication from the public portal for the purpose of private study or research.

- You may not further distribute the material or use it for any profit-making activity or commercial gain

- You may freely distribute the URL identifying the publication in the public portal 


\title{
Diffusion of phosphorous in black silicon
}

\author{
Andreas R. Stilling-Andersen, Olga Solodovnikova, Rasmus S. Davidsen, Ole Hansen and Beniamino \\ Iandolo
}
Technical University of Denmark, Department of Micro-and Nanotechnology, Ørsteds plads 345 C, Kgs. Lyngby, DK-2800, Denmark

\begin{abstract}
Black silicon is a promising texturing method for solar cells since it suppresses optical reflection in a broad spectral range. This relaxes the usual antireflection requirements on the coatings used for surface passivation of silicon. Fabrication of n-type emitters requires diffusion of phosphorous through the nanostructures of black silicon, which may need different optimal conditions as compared to diffusion through $e$.g. pyramidal wetetched structures due to the different characteristic dimensions. In addition, the diffusion process should ideally not deteriorate the antireflective properties of black silicon. Here, we have investigated the effect of temperature and time during the doping process on optical reflectance and sheet resistance of black silicon. Doping temperatures of $875{ }^{\circ} \mathrm{C}$ and lower result in negligible increase of reflectance as compared to pristine black silicon. In addition, the sheet resistance of black silicon emitters is confirmed to be lower than that of planar $\mathrm{Si}$ under identical annealing conditions.
\end{abstract}

Index Terms — black silicon, phosphorous emitter, diffusion

\section{INTRODUCTION}

Black silicon (bSi) [1,2] has great potential as texturing method for Si-based photovoltaics thanks to its intrinsic antireflective properties both at normal and at high angle of incidence of light [3]. Power conversion efficiencies between 18 and $22 \%$ have been achieved in the lab on bSi solar cells using laser-doped selective emitters [4], interdigitated back contact (IBC) [5], and on multicrystalline substrates [6]. These results were obtained by texturing $\mathrm{Si}$ using maskless reactive ion etch (RIE). Maskless RIE is of commercial interest because: (i) it is a single-step process and therefore potentially industrially scalable, (ii) it works indifferently mono-, quasimono- and multicrystalline $\mathrm{Si}$, and (iii) can be used on diamond-wire cut wafers. Diffusion of phosphorous (P) in $\mathrm{p}$ type $\mathrm{Si}$ substrates is the de facto industrial standard for fabrication of emitters in back-surface field Si solar cells [7]. Diffusion of $\mathrm{P}$ through the nanostructures of bSi is likely to require different optimal conditions as compared to diffusion through e.g. pyramidal wet-etched structures due to the different characteristic dimensions. In addition, the diffusion process should ideally not increase the reflectance of bSi. Here, we have investigated the effect of temperature and time during the doping process on optical reflectance, morphology and sheet resistance of $\mathrm{bSi}$.

\section{METHODS}

All wafers were $100 \mathrm{~mm}, 350 \mu \mathrm{m}$ thick CZ p-type (100) Si. BSi was obtained by non-cryogenic RIE using a SPTS Pegasus system using the following process parameters: temperature of $-20{ }^{\circ} \mathrm{C}, \mathrm{SF}_{6}$ and $\mathrm{O}_{2}$ plasma with 7:10 gas flow ratio, total chamber pressure of $38 \mathrm{mT}$ Torr, $3000 \mathrm{~W}$ coil power, $10 \mathrm{~W}$ platen power and 14 min process time. The wafers where then cleaned using the standard RCA procedure. Doping with $\mathrm{P}$ was performed in a Tempress furnace with a pre-deposition step (with $\mathrm{POCl}_{3}$ vapors as a source of $\mathrm{P}$ ) followed by a drive-in step in $\mathrm{N}_{2}$ atmosphere. For each wafer, the temperature and time were the same for pre-deposition and drive-in. For different wafers, the temperature was varied between $850{ }^{\circ} \mathrm{C}$ and 1050 ${ }^{\circ} \mathrm{C}$, while the time was either 15 or $30 \mathrm{~min}$. Planar Si samples were doped along with textured wafers for reference purposes. P-doped glass layers were removed by etching in buffered hydrofluoric acid (bHF).

Scanning electron microscopy was performed in a VP 40 SEM (Zeiss) at an accelerating voltage of $10 \mathrm{kV}$. Reflectance measurements were carried out using a UV-2600 spectrophotometer (Shimadzu Co.) equipped with an integrating sphere. The sheet resistance was measured 10 times for each wafer using a FPP-500 (Veeco).

\section{RESULTS}

Reflectance measurements in the wavelength range 280 $1100 \mathrm{~nm}$ are shown in Fig. 1 for pristine bSi and for bSi surfaces after doping, as well as for a reference Si surface. The pristine $\mathrm{bSi}$ is characterized by reflectance lower than $5 \%$ in the range 300-1000 nm. Doping at temperature between $850{ }^{\circ} \mathrm{C}$ and 865 ${ }^{\circ} \mathrm{C}$ has a very similar effect on the reflectance, which increases to $10 \%$ or higher between 280 and $400 \mathrm{~nm}$ while remaining around $7 \%$ or lower throughout the visible and up to $1000 \mathrm{~nm}$. Doping temperatures between $875^{\circ} \mathrm{C}$ and $950{ }^{\circ} \mathrm{C}$ also results in rather similar reflectance spectra, with values larger than $15 \%$ in the UV and between $15 \%$ and $8 \%$ in the visible and NIR. Doping at $1050{ }^{\circ} \mathrm{C}$ results in a further, considerable increase in reflectance $30 \%$ or higher in the UV and at least $17 \%$ in the visible and NIR. These differences in reflectance can also be appreciated by the naked eye, as photographs of selected surfaces after doping show Figure 2. It is worth to note that these values of reflectance are most likely to drop further with 


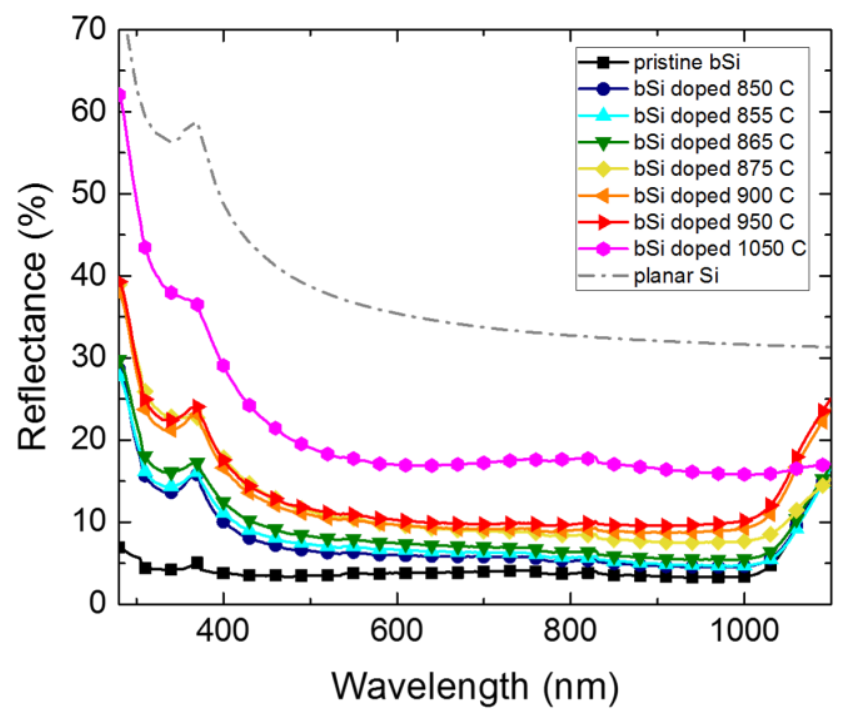

Fig.1. Optical reflectance in the wavelength range 280-1100 nm for pristine bSi before and after doping at different temperature, as well as for a planar reference Si surface.

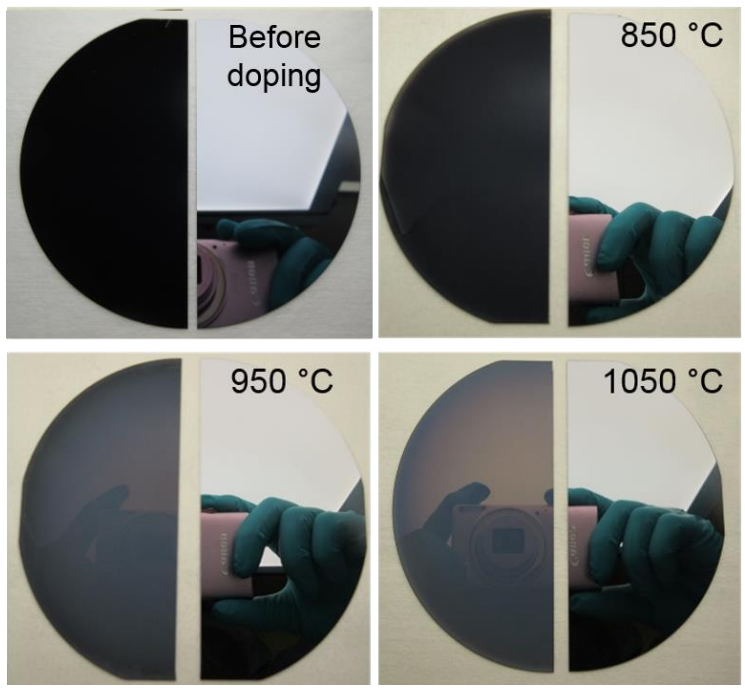

Fig.2. Photographs of bSi and planar reference Si before doping and after doping at different temperatures for $15 \mathrm{~min}$.

deposition of relevant coatings for passivation of $\mathrm{bSi}$ ( $\mathrm{SiN}_{\mathrm{x}}: \mathrm{H}, \mathrm{Al}_{2} \mathrm{O}_{3}$, or a stack of these two).

During the doping process, a layer of $\mathrm{P}$ doped glass is grown into the $\mathrm{Si}$, and subsequently removed by wet etch. This processing may lead to appreciable modifications of the nanostructures in the textured surface, depending on the process parameters. Indeed, cross-section SEM inspection reveals alterations in the morphology of all the textured surfaces following the doping process. Figure 3 shows a comparison between representative cross-section images of bSi before doping and after doping for $15 \mathrm{~min}$ at temperatures increasing from $850{ }^{\circ} \mathrm{C}$ to $1050{ }^{\circ} \mathrm{C}$ (from top to bottom). The texturing of the $850^{\circ} \mathrm{C}$ samples is almost unaffected by the processing and
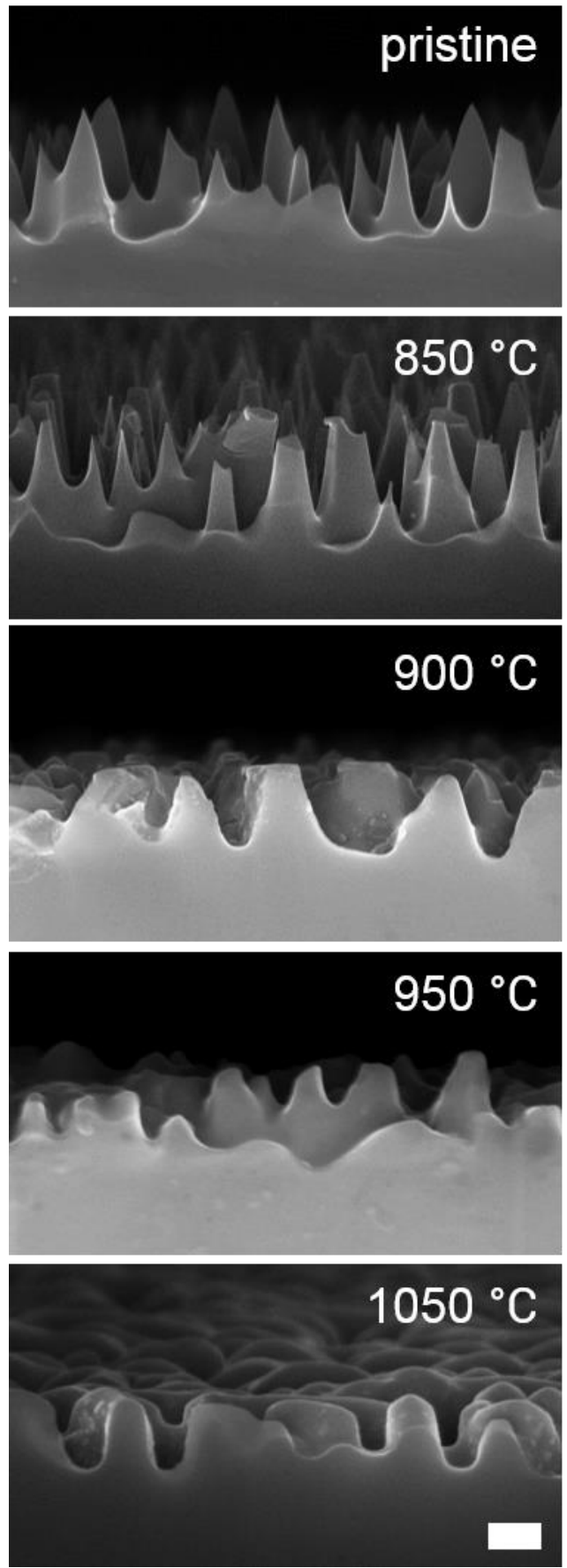

Fig. 3. Cross-section SEM images of pristine bSi and of bSi after doping at temperature increasing from $850{ }^{\circ} \mathrm{C}$ to $1050{ }^{\circ} \mathrm{C}$. The scale bar represents $200 \mathrm{~nm}$.

presents typical conical-like hillocks of height between 300 and $400 \mathrm{~nm}$. Only the tips of these hillocks seem to have been oxidized and subsequently etched in bHF, leaving slightly truncated features. Such a process is slightly more pronounced for the surface doped at $900{ }^{\circ} \mathrm{C}$, however the average height of the truncated hillock remains rather uniform. Doping at $950{ }^{\circ} \mathrm{C}$ results in smoothening of a considerable amount of features. Finally, doping at $1050{ }^{\circ} \mathrm{C}$ results in uniformly smoothed 

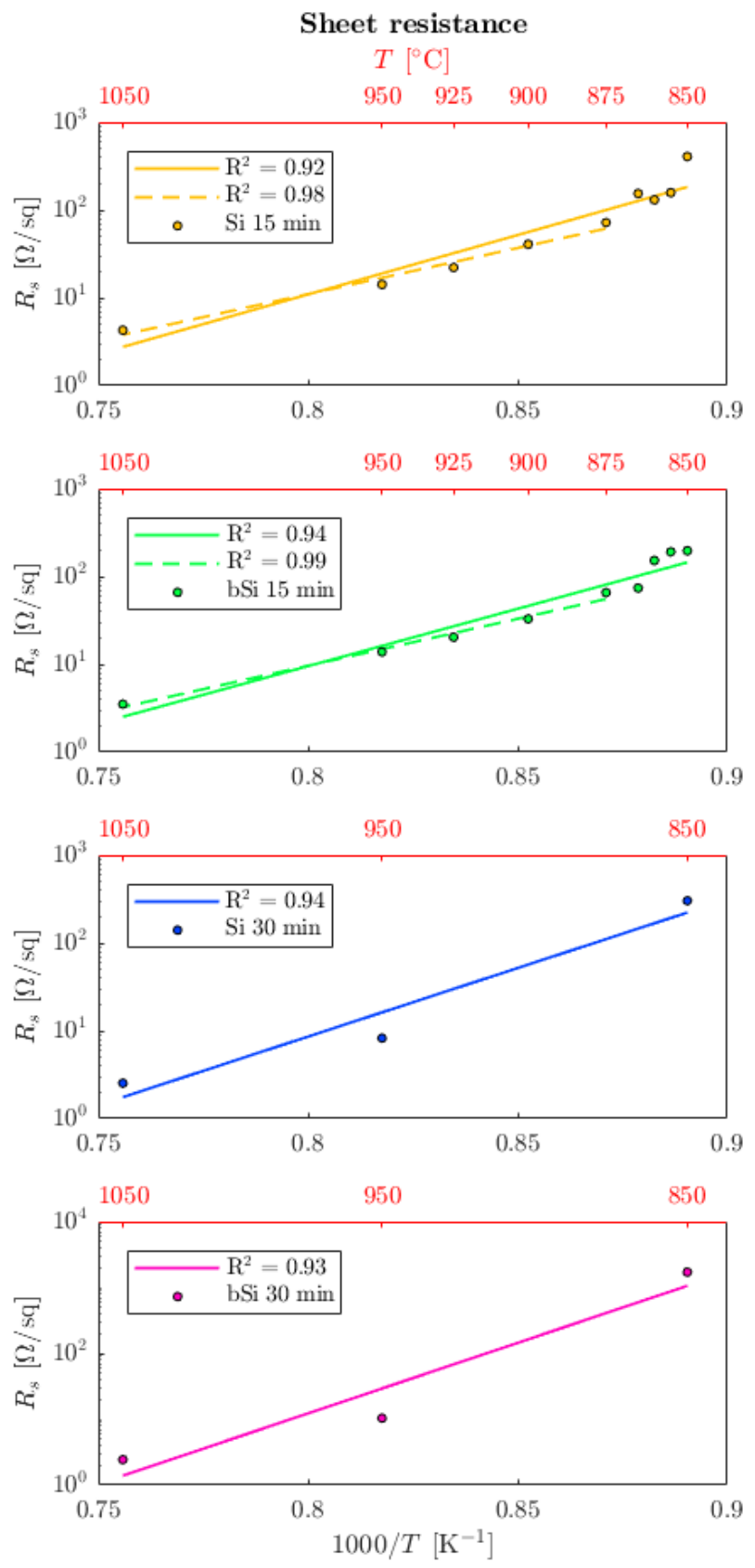

Fig. 4. Sheet resistance as function of inverse temperature for: 15 min doped flat $\mathrm{Si}, 15 \mathrm{~min}$ doped bSi, 30 min flat $\mathrm{Si}, 30 \mathrm{~min} b \mathrm{bi}$ (from top to bottom).

cylinder-like featured about half as high as the original hillocks. We conclude that the microscopic modification of the surface texturing due to the doping processing explain the increase in optical reflectance observed after higher doping process temperatures.

We performed macroscopic four point probes measurements in order to determine the sheet resistance of the fabricated $\mathrm{P}$ emitters. Decreasing values of sheet resistance were recorded for increasing temperatures, and for increasing time at the same temperature. Results are summarized in Figure 4, where the sheet resistance is plotted as function of inverse temperature. Data for both bSi and flat Si can be fit well by a straight line, which indicates that the diffusion coefficient has a temperature dependency that does not differ much from the behavior predicted by Arrhenius law. In addition, the sheet resistance of $\mathrm{bSi}$ is consistently lower than that measured on the corresponding planar Si reference by a factor between $10 \%$ and $20 \%$, depending on the process conditions. This is an experimental confirmation that diffusion of $\mathrm{P}$ is faster in $\mathrm{bSi}$ than in planar $\mathrm{Si}$ doped under the same conditions. Furthermore, we note that the bSi emitter doped at $865^{\circ} \mathrm{C}$ for 15 min shows a sheet resistance of $74 \Omega \mathrm{sq}^{-1}$, which is very promising for device fabrication. We conclude that such process conditions result in surface with respectable antireflective properties and appropriate emitter sheet resistance. Ideally, in order to obtain further quantitative information on the properties of the $p-n$ junctions fabricated here, the dopant profile in bSi should be directly measured. This is a rather challenging task for routine techniques such as secondary ion mass spectroscopy (SIMS), which is most reliable on polished surfaces. Scanning non-linear dielectric microscopy (SNDM) or electron holography may be more useful in this context. Electrochemical Capacitance-Voltage (ECV) measurements that account for the higher surface area of bSi by using a geometrical correction factor (as previously done for $\mathrm{KOH}$ etched pyramid surfaces) may also give useful information.

\section{CONCLUSIONS}

We have investigated the effect of temperature and time during the phosphorous doping process, leading to the formation of n-type emitters, on optical reflectance, morphology and sheet resistance of black silicon. Doping for $15 \mathrm{~min}$ at temperature between $850{ }^{\circ} \mathrm{C}$ and $865^{\circ} \mathrm{C}$ result in bSi surfaces with respectable antireflective properties (lower than $7 \%$ between 400 and $1000 \mathrm{~nm}$ ). The sheet resistance measured on bSi emitters is consistently lower (between $10 \%$ and $20 \%$ ) than that of planar $\mathrm{Si}$ doped under the same conditions. In particular, doping at $865^{\circ} \mathrm{C}$ results in a sheet resistance of 73.9 $\pm 0.2 \Omega \mathrm{sq}^{-1}$ suitable for device fabrication.

\section{ACKNOWLEDGEMENT}

This work was supported by funding from "Det Energiteknologiske Udviklings- og Demonstrationsprogram" EUDP (project number 64016-0030).

\section{REFERENCES}

[1] H. Jansen, M. de Boer, R. Legtenberg, and M. Elwenspoek. (1995). The black silicon method: a universal method for determining the parameter setting of a fluorine-based reactive ion 
etcher in deep silicon trench etching with profile control. Journal of Micromechanics and Microengineering, 5(2), 115.

[2] M. Otto et al. (2015). Black Silicon Photovoltaics. Adv. Optical Mater. 3, 147-164

[3] R.S. Davidsen, J. Ormstrup, M. L. Ommen, P. E. Larsen, M. S. Schmidt, A. Boisen, and O. Hansen. (2015). Angle resolved characterization of nanostructured and conventionally textured silicon solar cells. Solar Energy Materials and Solar Cells, 140, 134-140.

[4] R. S. Davidsen, H. Li, A. To, X. Wang, A. Han, J. An, A. Boisen, O. Hansen, S. Wenham, A. Barnett (2016). Black silicon laserdoped selective emitter solar cell with $18.1 \%$ efficiency. Solar Energy Materials and Solar Cells, 144, 740-747.
[5] H. Savin, P. Repo, G Von Gastrow, P. Ortega, E. Calle, M. Garín, and R. Alcubilla (2015). Black silicon solar cells with interdigitated back-contacts achieve $22.1 \%$ efficiency. Nature nanotechnology, 10(7), 624-628.

[6] J Benick, A. Richter, R. Müller, H. Hauser, F. Feldmann, P. Krenckel, and A. W. Bett, A. W. (2017). High-efficiency n-type HP mc silicon solar cells. IEEE Journal of Photovoltaics, 7(5), 1171-1175.

[7] H. Li, K. Kim, B. Hallam, B. Hoex, S. Wenham, M. Abbott (2017). $\mathrm{POCl}_{3}$ diffusion for industrial $\mathrm{Si}$ solar cell emitter formation. Front. Energy, 11(1), 42-51. 